\title{
Economic evaluation of Miscanthus production - A review
}

\section{Journal Article}

\section{Author(s):}

Witzel, Carl-Philipp; Finger, Robert (D)

Publication date:

2016-01

Permanent link:

https://doi.org/10.3929/ethz-b-000108799

\section{Rights / license:}

Creative Commons Attribution-NonCommercial-NoDerivatives 4.0 International

\section{Originally published in:}

Renewable and Sustainable Energy Reviews 53(681), https://doi.org/10.1016/j.rser.2015.08.063 


\section{Postprint}

This is the accepted version of a paper published in Renewable \& Sustainable Energy Reviews. This paper has been peer-reviewed but does not include the final publisher proofcorrections or journal pagination.

\section{Citation for the original published paper:}

Witzel, C.P., Finger, R. (2016). Economic evaluation of Miscanthus production - A review.

Renewable \& Sustainable Energy Reviews 53: 681-696.

https://doi.org/10.1016/j.rser.2015.08.063

Access to the published version may require subscription.

N.B. When citing this work, cite the original published paper. 
Economic evaluation of Miscanthus production - A review

Carl-Philipp Witzel ${ }^{\mathrm{a},}$, Robert Finger ${ }^{\mathrm{a} *}$

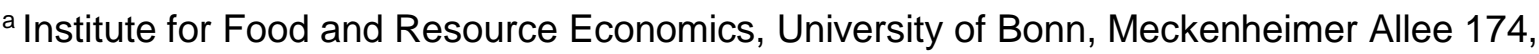
53115 Bonn, Germany

\section{Abstract}

This paper reviews the peer-reviewed literature dealing with the economics of Miscanthus cultivation, to identify factors influencing the adoption of Miscanthus and to reveal shortcomings in research. In total, 51 studies have been identified for this review. The majority of these publications are recent (i.e. the majority is published after 2009) and concern case studies in Europe (particularly the UK and Ireland) and North America. This review reveals that the economic viability of Miscanthus depends on largely uncertain assumptions especially concerning yields (10 - 48t dry matter per ha) and prices (48 - 134€/t dry matter) but also concerning the lifespan (10-20 years) and different cost items. A lack of established markets, high establishment costs and uncertainties, arising to a large extent from the long term commitment, are identified as major barriers to Miscanthus adoption. In addition, the level of support for Miscanthus production (e.g. via subsidies) is identified as crucial for Miscanthus profitability, but is found to be highly heterogeneous across countries. Next to diversity in agronomic and economic assumptions, also the assessment criteria and research techniques used to investigate the profitability of Miscanthus differ widely. While the net present value criterion was most frequently used, we identify a lack of approaches that account for risks and uncertainties, which seem to potentially play a critical role in the uptake of Miscanthus by farmers.

Keywords: Miscanthus; profitability; adoption decision; perennial energy crop; bioenergy

\footnotetext{
* Corresponding author: Tel.: +49 (0)228 73-2890. E-mail address: r.finger@ilr.uni-bonn.de
} 


\section{Introduction}

Problems related to $\mathrm{CO}_{2}$ emissions and increasing worldwide demand for energy reveal a discrepancy between ecological and economic objectives [1]. Therefore, energy sources with a high degree of sustainability in terms of $\mathrm{CO}_{2}$ reduction but still ensuring the security of supply are required [2, 3]. High yielding perennial energy crops are expected to contribute to developments in this direction by providing $\mathrm{CO}_{2}$ "neutral" feedstock for energy production [4].

Despite this potentially high demand for renewable energy in the future, supported by various national and transnational climate politics and targets such as a $10 \%$ increase in energy use efficiency and a share of $20 \%$ of energy supply from "renewables" in the EU up to 2020 [5], the adoption of dedicated perennial biomass crops by farmers remains low [6]. While the contribution of renewable energy from hydro energy plants, wind turbines, solar energy and especially biomass (wood residues, renewable wastes) is remarkable [7], perennial energy crops play a minor role in terms of growing volume [8]. This observation contrasts the finding that perennial energy crops might be interesting for farmers from a financial point of view [9, 10] and thus may have a massive potential for renewable energy provision. From a societal perspective, energy production which is less dependent from "stochastic" events like sunshine and wind (which are necessary for solar and wind power generation) should be favored, since constantly available energy supply at any day and night time can be seen as a fundamental pillar of welfare [11]. Hence, it is not surprising that the worldwide share of woody biomass dedicated for energy production amounts to more than $50 \%$ of the total harvested woody biomass ( $>1.85$ of the total 3.6 billion $\mathrm{m}^{3}$ round wood in 2013 [12]) leading to a progressive depletion of natural timber resources [13]. As advantages of biomass for energy purposes are obvious on the one hand and natural resources are in danger on the other hand, viable substitutes for natural grown wood have to be identified. In this context, several perennial energy crops are considered as interesting alternatives, e.g. Switchgrass (Panicum virgatum) 
which has been assessed thoroughly in the USA as a potential high yielding biomass plant [14-16] or the cultivation of fast growing trees in short rotation coppices (src) $[6,17,18]$. Of particular importance is also Miscanthus because of its unique combination of unpretentiousness regarding management, soil properties and climate with a high annual yield potential over a lifespan of up to 20 years. Furthermore, it has been shown that Miscanthus is one of the most productive bioenergy crops $[15,19,20]$ (e.g. compared to src) converting solar energy into biomass energy up to $30 \%$ more efficiently than other crops due to its C4 type of photosynthesis [21], requiring only low nutrient applications [22] while at the same time providing environmental benefits such as sequestration of carbon in the soil, protection against erosion, removal of heavy metals or increased biodiversity [20], [23], [24], [25]. Thus, based on these and other indicators Miscanthus performs well in comparison to other biomass sources (e.g. [26, 27]). Despite this potential relevant role of Miscanthus, little evidence regarding its economic viability has been provided and no systematic review of these aspects has been conducted across different production, economic and political systems. Furthermore, neither systematic information on drivers and barriers of adoption have been provided, nor have been the methodological assumption underlying the economic assessment of Miscanthus been critically reviewed. This article aims to contribute to fill these research gaps by reviewing the existing scientific literature dealing with the economics of Miscanthus production to identify factors influencing the adoption of Miscanthus and to reveal shortcomings in research that require further examination. Such review is potentially relevant for further scientific research dealing with the economic and agronomic aspects of Miscanthus cultivation and especially with the process of decision making of farmers concerning Miscanthus (and comparable biomass crops) adoption. In addition, this review provides valuable information to those who are involved in promoting sustainable energy production such as extension services and politicians. To them, this review will serve as guideline, leading to a more sophisticated and realistic insight in the economics of Miscanthus production. 
The remainder of this article is structured as follows: First, general aspects of Miscanthus cultivation and key characteristics are presented in section 2. Next, the review procedure is presented in section 3 containing a description of the examined literature. Subsequently, results concerning costs and benefits of Miscanthus cultivation are presented in section 4 . Shortcomings and implications for future research are discussed in section 5 followed by a conclusion in section 6 .

\section{Background on Miscanthus production}

Miscanthus is a large perennial and rhizomatous grass which was imported to Europe from East-Asia as an ornamental plant in the 1930's [22]. While there is a large variety of Miscanthus species, literature assessing the economics of Miscanthus cultivation nearly exclusively deals with Miscanthus $x$ Giganteus [28] which is a hybrid of Miscanthus sinensis and Miscanthus sacchiflorus [29]. In this paper it is referred to it as Miscanthus. Besides using Miscanthus for energetic uses, this perennial crop has also potential to serve as feedstock for textiles or construction materials [29,30]. With its C4 photosynthesis process, typical for grasses of arid regions like sugar cane, millet or corn, Miscanthus converts sunlight energy more efficiently into biomass energy than $\mathrm{C} 3$ crops and has the ability to cope with dry and hot locations that are exposed to high solar radiation, comparable to cropland which is alternatively dedicated to corn production [28, 31]. Nevertheless also in cooler climates Miscanthus has proven high productivity, which qualifies it as potential biomass plant for a central to northern European setting, where a high demand for biomass for energy and other uses is apparent (e.g. [5]).

Miscanthus (Miscanthus $x$ Giganteus) is considered as a sterile and non-invasive plant. Therefore vegetative propagation of Miscanthus is required [28]. Plantation of rhizomes or precultivated plantlets (micro-propagation) with a density of 1 [32] - 2 [25] per $\mathrm{m}^{2}$ takes place in spring with attention to frost since rhizomes are sensitive to temperatures lower than $-3^{\circ} \mathrm{C}[22]$. After soil preparation and plantation, which can be carried out mostly with common farm equipment such as ploughs and a (modified) potato planter [29], an establishment period of 2 
[33] to 4 [34] years follows, where only limited biomass yields are achieved. During this establishment period maintenance work such as weed control and replanting of frost losses is necessary until Miscanthus reaches its full competitiveness [29]. Fertilization needs are low compared to conventional crops, but clearly depend on soil properties and nutrient removal from the field. The latter depends in particular on the harvest date [28]. Storing huge amounts of nutrients such as $\mathrm{N}$ and $\mathrm{K}$ in its rhizomes during winter, a harvest date in spring allows Miscanthus to get along with low fertilization since only the withered above-ground parts of the plants are harvested [28]. Additionally, only stems are harvested, while the litter remains on the ground, forming a layer of mulch. Another advantage of a late harvest date is the high share of dry matter (moisture content 15\% [30]) with low mineral content of the harvested material thus leading to reduced costs for transport, storage and a higher (calorific) quality [22]. Harvest can be carried out with conventional farm equipment like self-propelled corn harvesters and balers. Due to the high costs of this machinery, Miscanthus harvest is usually outsourced to contractors [9] ${ }^{1}$. The yield potential of a fully established $3-4 \mathrm{~m}$ tall Miscanthus plantation usually reaches from 10 to $20 \mathrm{t} \mathrm{dm} / \mathrm{ha}$ (tons dry matter per ha) [35] although extremes range from 2.5 [36] to $60 \mathrm{t} \mathrm{dm} / \mathrm{ha}$ [37] depending on local agronomic conditions. The energy content of Miscanthus is comparable to wood with around $17 \mathrm{MJ} / \mathrm{t}^{2}$ (mega joule per ton) $[38,39]$ potentially enabling Miscanthus to act as substitute for woody biomass.

As a perennial crop, Miscanthus needs to be planted only once (apart from selective replanting after the first winter) and afterwards provides annual yields over a lifespan of 10 [36] to 20 [40] years. At the end of its lifespan, when yields are decreasing, the Miscanthus plantation is closed using herbicides (e.g. glyphosate) to kill the plants and underground parts of the plant are removed [9].

\footnotetext{
${ }^{1}$ The fact that demand for this equipment is not within the time-window of maize harvesting is nevertheless assumed to be an advantage for the availability and the price of the contractor. ${ }^{2}$ Calorific value of Miscanthus depends on moisture content, storage conditions and the composition of the feedstock. Thus, precise energy yields have to be calculated for each case individually.
} 


\section{Literature review and data collection}

\subsection{Literature processing}

A comprehensive literature review was conducted to create an overview about the entirety of scientific papers dealing with the economics of Miscanthus cultivation. The databases Google Scholar, Web of Science ${ }^{\mathrm{TM}}$ and ScienceDirect@ $\odot$ were screened for "Miscanthus" plus the following keywords: farm level, decision, adoption, cost, return, competitiveness, profit, NPV, benefits, economics, margin, viability, feasibility, real option, biomass and bioenergy. The total number of identified titles (16.353) was screened for economic relevance and if found to be suitable, transferred to Citavi 4.4. The collection of papers was conducted in the beginning of January 2015, so that only papers till 2014 are considered. We focused on peer-reviewed papers published in journals and refrained from dissertations, conference papers (except for 3 papers considered as particularly valuable [41-43]) and other not peer-reviewed articles found during the literature review. Of the initially found 16353 titles, 96 were found to be relevant in a wider sense. Those pre-selected 96 titles were then scanned thoroughly for their content (the list of these papers is available from the authors upon request). Finally 51 papers were identified as suitable, 45 papers were rejected for different reasons such as doublets, Miscanthus being only superficially addressed, objectives of papers not being economic but mainly technical aspects of Miscanthus cultivation or incomplete sources ${ }^{3}$. Other studies have been not considered further because they focused on the use of Miscanthus for electricity or fuel generation or on the influences of certain soil qualities, but did not focus on economic aspects.

\footnotetext{
${ }^{3}$ This refers to the fact that despite efforts four titles exported to Citavi could not be made available and are therefore not considered.
} 
Figure 1: Illustration of the literature reviewing procedure

Figure 1: The numbers in brackets represent the number of studies on each step of the procedure. The numbers next to the arrows represent the studies excluded during the review process.

The selected papers were surveyed with respect to a wide range of items, concerning i) the origin of the study and the year of its publication, ii) the methods used in the investigation, iii) assumptions made in the assessment. These comprise details on the production process e.g. whether Miscanthus is harvested with a chipper or with a baler, costs, discount rates, the reference system used to compare Miscanthus cultivation to other businesses e.g. corn or soybean production, lifespan and harvest time, yields, prices and financial support by subsidization. Our aim was to identify those factors that are most crucial for the profitability of Miscanthus and thus are considered to be critical for the farmers' decision regarding the adoption of Miscanthus. This causal relation between profitability and adoption of a crop is based on the assumption that farmers will only be willing to change their conventional farming business, if the alternative provides them at least with the same profits or utility ${ }^{4}$ than the current farm business [15], [44]. To capture the entire range of possibly decisive factors, the initial data collection process had a wide perspective to avoid that potentially important information were omitted. In this review, we restrict the presentation to factors that have been found to be most important and information, where an amount of data could be retrieved that allows for comparison across studies. For instance, assumptions on the potentially available area of land that could be committed to Miscanthus on a national level were not seen as

\footnotetext{
${ }^{4}$ Extending the profit framework towards utility allows to also consider aspects of uncertainty, which are of highest relevance for farmers' decision to adopt perennial energy crops (e.g. [18]).
} 
important decision basis for single farmers, while information about assumed lifespans of Miscanthus or applied discount rates were seen as highly interesting for adoption decisions. Furthermore, at this stage of the review process, adjustments were made to make the papers originating from different countries comparable. Hence, all prices and costs, stated in different currencies, were transferred to Euro using the respective exchange rates ${ }^{5}$ from February $10^{\text {th }}$ 2015. An overview about the reviewed literature together with selected core information extracted from the examined papers is provided in table 1

\footnotetext{
${ }^{5}$ The respective exchange rates used in our analysis are: 1 US $\$=0.884 € ; 1$ CAN $\$=0.707 € ; 1 £=1.345 €$ (taken from www.oanda.com).
} 
Table I: Literature summary, overview and description of the reviewed literature

\begin{tabular}{|c|c|c|c|c|c|c|c|c|c|c|c|}
\hline No. & Country & $\begin{array}{l}\text { Publishing } \\
\text { date }\end{array}$ & Reference system & Utilization & $\begin{array}{l}\text { Total } \\
\text { lifespan } \\
\text { in years }\end{array}$ & $\begin{array}{c}\text { First } \\
\text { harvest } \\
\text { year }\end{array}$ & $\begin{array}{l}\text { Mean yield } \\
\text { (in } t \mathrm{dm} / \mathrm{ha} \text { ) }\end{array}$ & $\begin{array}{l}\text { Mean } \\
\text { prices } \\
\text { (in } € / \mathrm{t} \mathrm{dm} \text { ) }\end{array}$ & $\begin{array}{l}\text { Discount } \\
\text { rate } \\
\text { (in \%) }\end{array}$ & $\begin{array}{l}\text { model/ } \\
\text { method }\end{array}$ & References \\
\hline 1. & UK & 2012 & src & & 16 & 2 & 12.80 & 80.71 & 6 & $\begin{array}{l}\text { NPV, AGM, EU, } \\
\text { SA }\end{array}$ & [45] \\
\hline 2. & UK & 2008 & src willow & $\mathrm{dc}, \mathrm{cf}$, bedding & & 4 & & & & & [44] \\
\hline 3. & UK & 2013 & & $\begin{array}{l}\text { dc, cf, btl, } \\
\text { bedding }\end{array}$ & & & 12.00 & 77.30 & & & {$[38]$} \\
\hline 4. & UK & 2012 & & $\mathrm{dc}$ & & & & & & & [46] \\
\hline 5. & UK & 2013 & & $d c$ & & & 12.00 & & & SA & {$[47]$} \\
\hline 6. & UK & 2010 & src willow & $\mathrm{dc}, \mathrm{cf}$ & & & 14.00 & 80.71 & 6 & $\begin{array}{l}\text { NPV, AN, AGM, } \\
\text { SA }\end{array}$ & {$[48]$} \\
\hline 7. & UK & 2012 & & dc, cf & 20 & 2 & 10.45 & 62.04 & & SA, CBA & [49] \\
\hline 8. & UK & 2013 & src & $\mathrm{dc}$ & 16 & 2 & 14.00 & 80.71 & 6 & SA & [50] \\
\hline 9. & UK & 2010 & src & cf, btl & 21 & 4 & & & 6 & $\begin{array}{l}\mathrm{NPV}, \mathrm{SA}, \mathrm{CBA}, \\
\mathrm{BEC}\end{array}$ & [51] \\
\hline 10. & UK & 2014 & & $\mathrm{cf}, \mathrm{btl}$ & & & & 134.51 & $6 ; 8 ; 9 ; 11 ; 13$ & $\mathrm{NPV}, \mathrm{SA}$ & [52] \\
\hline 11. & UK & 2013 & src willow & $\mathrm{dc}, \mathrm{cf}, \mathrm{btl}$ & 20 & 3 & & & & & [53] \\
\hline 12. & $\begin{array}{l}\text { PL, HU, } \\
\text { UK, IT, } \\
\text { LI }\end{array}$ & 2009 & switchgrass & $\begin{array}{l}\mathrm{dc}, \mathrm{cf}, \mathrm{btl}, \\
\text { pulp, plastics, } \\
\text { construction }\end{array}$ & 15 & 2 & & & & NPV, AN, SA & [25] \\
\hline
\end{tabular}




\begin{tabular}{|c|c|c|c|c|c|c|c|c|c|c|c|}
\hline 13. & IRL & 2009 & src willow & dc, cf & 16 & 3 & 10.00 & 60.00 & 5 & NPV, IRR & [54] \\
\hline 14. & IRL & 2010 & src willow & cf & 16 & 2 & 12.68 & 86.00 & & NPV, MCS, RLH & [10] \\
\hline 15. & IRL & 2009 & $\begin{array}{l}\text { wheat, sugar beet, } \\
\text { triticale, straw, fossil } \\
\text { fuel }\end{array}$ & cf, btl & 16 & & 16.00 & 60.00 & 7 & SA, BEC & [55] \\
\hline 16. & IRL & 2008 & src willow & $\mathrm{dc}, \mathrm{cf}$ & 20 & 3 & 10.00 & & 5 & NPV & [43] \\
\hline 17. & IRL & 2008 & src willow & $d c, c f$ & & & & & & $\begin{array}{l}\text { NPV, AN, AGM, } \\
\text { MCS }\end{array}$ & [42] \\
\hline 18. & IRL & 2011 & src willow, coal & $d c, c f$ & 16 & 3 & 10.00 & 65.00 & 5 & NPV & [56] \\
\hline 19. & IRL & 2007 & src willow & $\mathrm{dc}, \mathrm{cf}$ & 16 & 3 & & 63.00 & 5 & NPV, CA & [9] \\
\hline 20. & IRL & 2013 & & $d c$ & 21 & 4 & 12.00 & 75.00 & 5 & NPV, AGM, BEC & [57] \\
\hline 21. & IRL & 2011 & straw, src willow & $\overline{b t l}$ & 22 & 2 & 18.00 & & & CA & [33] \\
\hline 22. & IRL & 2011 & $\begin{array}{l}\text { grass, src willow, oil } \\
\text { seed rape }\end{array}$ & & & & & & & & [58] \\
\hline 23. & IRL & 2011 & & & & & & & & & [59] \\
\hline 24. & US & 2011 & & dc, btl & 15 & 3 & 20.00 & 75.04 & & NPV, SA & [60] \\
\hline 25. & US & 2010 & switchgrass, coal & dc, cf, btl & 10 & & $\begin{array}{l}12.39 \\
13.04\end{array}$ & & & SA, BEC & [32] \\
\hline 26. & US & 2011 & $\begin{array}{l}\text { corn stover, } \\
\text { switchgrass, prairie } \\
\text { grasses, src poplar }\end{array}$ & btl & 15 & 2 & $\begin{array}{l}29.54 \\
25.16 \\
15.45\end{array}$ & & & NPV, CBA, BEC & [61] \\
\hline 27. & US & 2010 & $\begin{array}{l}\text { poplar, switchgrass, } \\
\text { mixed grasses, } \\
\text { canola, prairie }\end{array}$ & btl & 10 & 3 & 22.40 & 52.97 & 5 & BEC & [62] \\
\hline
\end{tabular}




\begin{tabular}{|c|c|c|c|c|c|c|c|c|c|c|c|}
\hline 28. & US & 2008 & & & & & & & & & [63] \\
\hline 29. & US & 2012 & & & & & & & & & [64] \\
\hline 30. & US & 2011 & & & & & & & & & [24] \\
\hline 31. & US & 2010 & switchgrass, coal & dc, cf & 20 & & & & 4 & NPV, SA & [65] \\
\hline 32. & US & 2008 & switchgrass, coal & $\mathrm{dc}, \mathrm{cf}, \mathrm{btl}$ & 20 & 3 & 35.80 & & 4 & SA, CBA, BEC & [20] \\
\hline 33. & US & 2009 & switchgrass & btl & & & 48.50 & & & & [37] \\
\hline 34. & US & 2010 & switchgras & btl, chemicals & 15 & 3 & 37.20 & & 4 & $\begin{array}{l}\text { NPV, SA, CBA, } \\
\text { BEC }\end{array}$ & [15] \\
\hline 35. & US & 2014 & switchgrass & $\mathrm{dc}, \mathrm{cf}, \mathrm{btl}$ & 15 & 4 & $\begin{array}{l}21.81 \\
23.60\end{array}$ & 48.56 & & MCS & [16] \\
\hline 36. & GR & 2000 & $\begin{array}{l}\text { src willow, poplar, } \\
\text { eucalyptus }\end{array}$ & & & & 20.30 & & & CBA & [39] \\
\hline 37. & GR & 2010 & $\begin{array}{l}\text { arundo, switchgrass, } \\
\text { cardoon }\end{array}$ & & 20 & & 11.28 & & & IRR, CA & [66] \\
\hline 38. & $\mathrm{~F}$ & 2010 & src, switchgrass & $\mathrm{dc}$ & 15 & 4 & 17.00 & 70.00 & 5 & $\begin{array}{l}\text { NPV, AGM, } \\
\text { SA,MCS, EU, DU, }\end{array}$ & [67] \\
\hline 39. & $\mathrm{~F}$ & 2011 & & & & 3 & & & & NPV & [41] \\
\hline 40. & $\mathrm{~F}$ & 2009 & & btl & 17 & 4 & 18.50 & 90.00 & & & [68] \\
\hline 41. & $\mathrm{~F}$ & 2014 & & & & & & & & BRT & [69] \\
\hline 42. & IT & 2014 & $\begin{array}{l}\text { oil and coconut palm, } \\
\text { jatropha, castor bean, } \\
\text { sunflower, rapeseed, } \\
\text { sugar cane, maize, } \\
\text { wheat, src poplar, }\end{array}$ & $d c, b t l$ & 15 & & 18.00 & 55.00 & 10 & NPV, CBA & [19] \\
\hline
\end{tabular}




\begin{tabular}{|c|c|c|c|c|c|c|c|c|c|c|c|}
\hline 42. & & & $\begin{array}{l}\text { cardoon, giant reed, } \\
\text { switchgrass, fiber } \\
\text { sorghum }\end{array}$ & & & & & & & & \\
\hline 43. & $\mathrm{CZ}$ & 2012 & & dc & 10 & 3 & & & 8.7 & NPV & [36] \\
\hline 44. & $\overline{P L}$ & 2012 & src willow, triticale & dc & 20 & 4 & 14.00 & 70.30 & 6.0 & NPV, AN, SA & [34] \\
\hline 45. & GE & 2012 & src poplar & $\mathrm{dc}$ & 21 & 3 & & 89.38 & & AN, MCS & [70] \\
\hline 46. & $\mathrm{NL}$ & 1999 & src willow & $\begin{array}{l}\mathrm{dc}, \\
\text { construction }\end{array}$ & 15 & 3 & 20.00 & & & & [30] \\
\hline 47. & $\mathrm{NL}$ & 2010 & sugar beet & btl & 20 & & & & 5.5 & NPV & [40] \\
\hline 48. & CAN & 2013 & switchgrass & $\begin{array}{l}\text { dc, cf, btl, } \\
\text { bedding }\end{array}$ & 15 & 3 & 29.60 & & 5 & NPV, BEC & [71] \\
\hline 49. & CAN & 2012 & & $\mathrm{dc}, \mathrm{cf}$ & 20 & 3 & & & 5 & NPV,SA, BEC & [72] \\
\hline 50. & TW & 2011 & switchgrass & $\mathrm{dc}, \mathrm{cf}, \mathrm{btl}$ & $10-20$ & & & & & LCP & [73] \\
\hline 51. & SW & 2009 & $\begin{array}{l}\text { src willow, poplar, } \\
\text { eucalyptus, reed } \\
\text { canary grass, switch } \\
\text { grass, hemp, triticale, } \\
\text { sorghum }\end{array}$ & $\mathrm{dc}, \mathrm{btl}$ & 21 & & 14.00 & 79.92 & 6 & NPV, AN & [23] \\
\hline
\end{tabular}

Explanation of abbreviations: UK= United Kingdom; PL= Poland; HU= Hungary; IT= Italy; LI= Lithuania; IRL= Ireland; US= United States; GR= Greece; F= France; CZ= Czech, GE= Germany; NL=

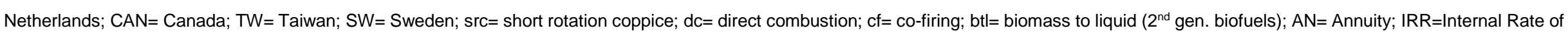
Return; NPV= Net Present Value; AGM= Annual Gross Margin; RLH= Repetitive Latin Hypercube Sampling; MCS= Monte Carlo Simulation; EU= Expected Utility Approach; DU= Discounted Utility; $\mathrm{SA}=$ Sensitivity Analysis; BRT= Boosted Regression Tree; $\mathrm{LCP}=$ Linear Complementary Problem; CBA= Cost-Benefit Analysis, CA= Cost Accounting, BEC= Break-Even Cost Analysis 


\subsection{Literature description}

\subsubsection{Origin and date of publication}

The 51 articles identified assess the situation from 16 different countries located in the EU ${ }^{6}$ (36 articles), North America (14 articles) and Asia (1 article) which might reflect the concentration of research regarding the production of this kind of biomass in some parts of the world (Figure 2).

Figure 2: Published papers on Miscanthus economics differentiated by regions

Figure 2: Total number of reviewed paper: $n=51$

Within the EU, the UK $(n=12)$ and Ireland $(n=11)$ seem to be most involved in exploring the economics of Miscanthus cultivation. North America is mainly presented by the US with 12 articles. The remaining 16 papers are spread over 10 different countries. This concentration of Miscanthus research in very few countries also reveals the incentives set by individual national politics to foster the adoption of perennial biomass plants. For instance, the UK and Ireland are responsible for almost 2/3 of the articles published on EU countries. Both, the UK and Ireland, have in common, that they offer ${ }^{7}$ substantial establishment grants of up to $50 \%$ of the total costs of establishing src or Miscanthus plantations to farmers plus additional per ha payments of up to $80 €$ per year $[9,45,47]$. A similar promotion of perennials can be observed in the US under the "Biomass Crop Assistance Program" (BCAP) which offers

\footnotetext{
${ }^{6}$ As no European studies outside of the EU have been found, EU and Europe are used interchangeably in our analysis.

${ }^{7}$ For instance, "Energy Crop Scheme" (ECS) in the case of the UK [45] and the "Bioenergy Scheme" in Ireland [9].
} 
establishment grants of up to $75 \%$ and support payments per ton or per ha of produced biomass [16, 37].

The distribution of the appearance of papers (year of publication) over time is provided in figure 3, showing that the earliest identified paper originates from 1999.

Figure 3: Number of studies published per year between 1999 and 2014

Figure 3 shows the total number of papers $(n=51)$ distributed according to their publishing year.

An increase in publication activity is particularly revealed around the years 2008 and 2010, which might indicate an increased societal and political interest in economics of renewable energies. Again, specific policy measures could be a reason for the increased number of publications. The "Food, Conservation, and Energy Act" released in June 2008 for example, a US subsidization program, offering 288 billion US\$ over a period of five years to the agricultural sector including research and development of advanced biofuels and the production of biomass [74] could have incentivized research in this area. Another example for politics that are suitable to increase interest in biomass related research is a renewable energy feed in tariff (REFIT), released by the Irish government in 2007 to achieve, beside other targets, a 30\% substitution of peat by biomass in selected power stations until $2015[43,56]$. However, this should not be overestimated since the total number of studies dealing with economics of Miscanthus remains low, compared to other sources of renewable energy (see e.g. $[75,76,77]$ for reviews on other renewable energy sources such as src, waste biomass and corn, respectively).

\subsubsection{System of comparison}

In order to assess the economic viability of Miscanthus relative to alternative crops or energy plants, the majority of publications choose to compare the cultivation of Miscanthus with the 
cultivation of short rotation coppice (src). More specifically, 23 out of the 51 publications (45\%) used src as a reference system for Miscanthus. 13 articles (25\%) do not mention any reference crop. Of those 23 publications assessing the economics of src, most focused on the short rotation cultivation of willow (15), 6 publications chose src poplar, 4 do not specify the kind of src and 2 publications assess the economics of src eucalyptus ${ }^{8}$. Note that due to the fact, that some publications use more than one src plant as reference crop, the numbers do not sum up to 23. The second largest share of reference crops is represented by large grasses and here especially Switchgrass plays a major role (see Table 1). Depending on the cropping site Miscanthus most often shows substantially higher yield potentials than Switchgrass $[15,16]$ although there are also examples where Switchgrass outmatches Miscanthus in terms of per ha yields [32]. Only few articles compared the profitability of Miscanthus with "traditional" crops such as wheat or corn, which often are the most dominant form of land use. Another area for comparison of Miscanthus is with fossil fuels in 5 articles to assess the competitiveness of Miscanthus as potential substitute mainly for coal. Even more concentrated than the origin of publications is the focus on the potential utilization pathways of Miscanthus. Of those publications that consider at least one Miscanthus utilization explicitly $(n=41), 100 \%$ regard Miscanthus as feedstock for heat and/or energy production. For the majority of publications $(n=34)$ a direct use of Miscanthus as energy carrier either as separate combustion material or as feedstock for co-firing with coal or peat is the method of choice to generate value from Miscanthus. Although the potential to produce advanced biofuels based on ligno-cellulosic feedstock such as Miscanthus is mentioned in 21 articles this alternative utilization is mostly

\footnotetext{
${ }^{8}$ Note that the focus on specific tree species can also be due to the fact that legal regulations on the use of species do exist. According to [78], EU member states are advised to list fast growing tree species that are suitable for src. For instance willow, poplar, hazel, silver birch, sycamore, sweet chestnut and lime are eligible species for the "Bioenergy Crop Scheme" in the UK (for more information see https://www.gov.uk/energy-crops-scheme-terms-and-conditions-of-your-agreement). In Germany, the corresponding species are willow, poplar, black locust, birch, ash-tree, alder and oak [78].
} 
referred to very superficially. For instance, [23] states that the production of $2^{\text {nd }}$ generation biofuels made from ligno-cellulose has not yet been commercialized and thus currently not encourages the production of perennial energy crops. Other papers (e.g. $[52,71])$ simply mention the potential suitability of Miscanthus for further processed products without further specification, details and quantitative analysis. A deeper examination of the economics of ligno-cellulosic bioethanol production in Ireland is conducted by [55] and [33], who partly come to differing results. While both are concluding that, under a reformed tax regime ligno-cellulosic biofuels could possible become competitive with fossil fuels, [55] shows that with cheaper imports of bioethanol and biomass available, biofuel processors in Ireland would not be willing to demand domestically produced feedstock. Six publications $[15,25,30,38,44,71]$ at least mention a possible use such as animal bedding or construction material and only two of them address the possibility of the generation of higher value products such as chemicals and plastics, again without further specification. With the aim of economic assessment, the reviewed literature strongly focuses on one-sided utilization of Miscanthus, enabling only a limited sales market for low value products (e.g. for energy generation), limiting also the attractiveness for cultivation of Miscanthus compared to other channels of use.

\subsubsection{Methods of assessment applied in literature}

At least 20 different methods where applied to assess the profitability of Miscanthus. The net present value (NPV) is the most frequently used measure of profitability and was used in 25 articles. Since the adoption of Miscanthus is an investment that has to generate returns over a certain period of time in order to cover the initial establishment costs, decision makers have to discount expected future cash flows, using an "appropriate" discount factor, to find out if the initial investment pays off. The NPV is one output value of the discounted cash flow method, showing todays value of future payments minus initial costs (other approaches based on discounted cash flows that are shown in figure 4 are the internal rate of return and the annuity method). 
In detail the distribution of different approaches looks as shown in figure 4. Although methods like surveys, expert interviews, geographic information tools (GIS) or choice experiments are no means of capital budgeting in the strict sense, they are nevertheless presented in figure 4 to provide a comprehensive overview of the applied methods.

Figure 4: Frequency of application of assessment criteria and research techniques used in literature

Explanation of abbreviations: NPV $=$ Net Present Value, $\mathrm{SA}=$ Sensitivity Analysis, FS= Farm Survey, BEC $=$ BreakEven Cost Analysis, GIS= Geographic Information System, CBA= Cost-Benefit Analysis, AN= Annuity, AGM= Annual Gross Margin, MCS $=$ Monte Carlo Simulation, $L P=$ Linear Programming Model, ABM= Agent-Based Model, $R A=$ Regression Analysis, $\mathrm{FG}=$ Focus Group, $\mathrm{CA}=$ Cost Accounting, $\mathrm{IRR}=$ Internal Rate of Return, EU= Expected Utility Approach, $\mathrm{CE}=$ Choice Experiment, BRT= Boosted Regression Tree, RLH= Repetitive Latin Hypercube Sampling, LCP $=$ Linear Complementary Problem.

Figure 4: Note that as the application of one model or technique does not exclude the application further techniques, the number of applications shown in figure 4 exceeds the total number of examined papers.

Due to the heterogeneity of methodological approaches used, there is no consistency to be expected neither with regards to the underlying research questions and assumptions nor with regard to the results. Nevertheless it becomes apparent across several methodological approaches that there are drivers and, above all, barriers that influence the decision of farmers whether to invest in growing Miscanthus or not. The influencing factors that were identified by the literature review are examined and discussed in the following section.

\section{Factors influencing the adoption and profitability of Miscanthus}

This section provides an overview on several aspects that influence the profitability and adoption of Miscanthus. It is divided in three main subsections that cover the technical and agronomic assumptions on Miscanthus cultivation as well as the costs and benefits of 
Miscanthus cultivation. Next to addressing the assumptions on average values used in the reviewed studies, a particular focus was also on the variability and uncertainty underlying the assumptions made. This is due to the fact that the few studies on Miscanthus profitability that do actually account for risks find that the major barrier to Miscanthus cultivation is, besides eventual technical problems, the uncertainty that farmers are exposed to concerning the profitability of their investment in that crop [42] [70]. Note that very mixed evidence was given by the studies whether Miscanthus does actually pay or not. Often, the reviewed studies refer to conditions (e.g. concerning future price and cost developments [37, 43-45, 62] or the availability of subsidies [40], contracts [23] and suitable soils [37] etc.) under which Miscanthus adoption could be profitable. To a large extent, the still limited uptake by farmers in practice does reveal that some significant adoption barriers are present under current conditions in many countries. Partly, we are going to address the barriers of adoption in the here presented analysis.

\subsection{Assumptions on Miscanthus cultivation}

\subsubsection{Lifespan}

The total lifespan of Miscanthus is the period from establishment till closing of the Miscanthus plantation. As Miscanthus is a perennial crop, this lifespan differs greatly from those of traditional crops which are cultivated from year to year providing the farmer with the opportunity to reallocate the land frequently to different crops. The long commitment of land to one single plant does not only limit the entrepreneurial freedom of the farmer which is seen as a major barrier to Miscanthus adoption by 7 of the reviewed papers [23, 42, 48, 54, 56-58] it also implies the fact that Miscanthus needs a minimum period to break even with the initial investment costs. The assumptions made in the studies show a large variety and range between 10 years [32, 62, 73] and 22 years [33] with a mean of 17 and a median of 16 years. Decreasing marginal biomass yields are claimed if exceeding the here indicated upper limits $[33,79,80]$. However, given these insights and given the fact that considering a longer lifetime 
and thus a larger number of harvest cycles can contribute to offset more of the initial costs, it is surprising that a 10 year lifecycle is assumed in some papers. The large variability in these assumptions reflects the high uncertainty with the production side of Miscanthus. This is due to the fact that Miscanthus is still a rather unexplored crop in many parts of the world and underlines the need for research and clear communication of agronomic insights in Miscanthus cultivation. Based on this background, a conservative assumption on the lifetime might be perceived by some authors as (misleading ${ }^{9}$ ) way to resolve problems of uncertainty. Figure 5 shows the great discrepancy with respect to the underlying lifespan assumptions in literature. While the range of the assumed lifetime is largest for Continental Europe followed by North America, UK and Ireland show slightly more consistent assumptions concerning the lifespan of Miscanthus. This might be due to the higher diversity of regions, climates etc. and the resulting data in Continental Europe and North America, while UK and Ireland face more similar production conditions. In addition, research dealing with the economics of Miscanthus in the UK and Ireland is strongly concentrated to a few research groups which might result in a more uniform database than in other regions.

Figure 5: Assumed Miscanthus lifespan differentiated by region

Figure 5: The individual countries are summarized to larger aggregates in figure 5 for improved comprehensibility. The number of considered studies is 10,10 and 14 for Continental Europe, North America and UK + Ireland respectively. The thick lines inside the boxes represent the respective median value.

\subsubsection{Establishment-to-revenue period}

\footnotetext{
${ }^{9}$ Conservative assumptions only would result in a critical level of undervaluing of any investment opportunity and thus result in strongly biased recommendations to farmers. A better methodological basis to deal with uncertainty is needed.
} 
As indicated in section 2, a period with strongly limited yields has to be overcome until the plantation is fully established and Miscanthus reaches its regular level of productivity [44]. During this establishment period costs for e.g. planting $[9,49]$ and maintenance $[34,71]$ occur while no revenues are generated [41] which may result in liquidity shortages of the farmhousehold [67]. The assumed first harvest of a fully operational Miscanthus plantation that provides regular yields varies between year 2 [10] and year 4 [16] with a mode of year 3 . Assuming that Miscanthus is planted in spring after last frosts (see section 2), almost one year

later (year 2; February till April [22]), Miscanthus shoots can be shredded and left on the field since harvest is not yet rational. One year later (year 3) first harvest can normally be conducted but with considerable limited yields due to the fact, that Miscanthus is still establishing. From year 4 onwards, (which means three years after planting), Miscanthus reaches its regular yield level. Considering this yield level development, the assumptions found in literature indicating regular yields from year 2 or 3 onwards might be too optimistic.

Figure 6 illustrates the distribution of expectations concerning first harvest which are stated in the examined literature. The variability found in these assumptions, again underlines the great uncertainty associated with the agronomic factors underlying Miscanthus production and thus the need for increased field trials and communication.

Figure 6: Expectations with regard to the date of first harvest with regular yields

Figure 6: 30 out of the 51 studies report a first regular harvest year ( 2 years: $n=8 ; 3$ years: $n=15 ; 4$ years: $n=7)$.

\subsection{Costs of Miscanthus cultivation}

Growing Miscanthus is related to various specific costs which differ by nature and amount from the costs caused by conventional annual crops. Those costs consist of single payments 
which are represented by the initial investment costs at the beginning and costs for closing the plantation at the end of its lifetime. Further, annual costs occur for harvest, transport and storage and maintenance. Additionally, opportunity costs of land and capital have to be taken into account. The former depending on potential alternative uses of the land committed to Miscanthus, the latter, accounted for by applying a certain discount rate, depending on potential revenues of alternative investments. Not all of these costs are of same relevance for the adoption decision of the farmer. In this section, these aspects are addressed in the given, i.e. chronological, order.

\subsubsection{Non-recurring payments}

\subsubsection{Establishment of the plantation}

The high upfront establishment costs are quoted as a major impediment for Miscanthus adoption $[9,45,58,62]$. However, the supply with detailed information about establishment cost is scarce in the examined literature. Therefore a comparison of the single cost items included in Miscanthus cultivation in all details is difficult. Thus, the following assessment is focused on the assumed total establishment costs of a Miscanthus plantation and the costs for Miscanthus rhizomes as they represent the largest share of total establishment costs. Figure 7 shows the range of mean total establishment costs quoted in literature $(n=19)$ and the range of costs for Miscanthus rhizomes per ha $(n=12)^{10}$.

Figure 7: Mean total establishment costs and costs of rhizomes per ha

Figure 7: Total mean establishment costs include, but are not limited to, activities such as land preparation, planting and re-planting, plant protection and, as the largest share, costs for Miscanthus rhizomes.

\footnotetext{
${ }^{10}$ Note that the latter are contained in the former in the presentation in Figure 7.
} 
The per ha costs for Miscanthus rhizomes range from 291.30€ [20] to 11410.00€ [62] (both US). Note that these outliers are not displayed in figure 7 . It has to be considered that the number of rhizomes used per ha varies strongly between $10.000[36,61]$ and $20.000[9,49]^{11}$. Assuming equal prices this means a potential doubling of material costs. However prices for Miscanthus rhizomes found in literature also strongly vary between $0.03 €$ [20] and $1.02 €$ [62] per piece. The "high cost scenario" for Miscanthus rhizomes assumed by [62] (1.02€/ per piece) relates to a field trial at the "Kellogg Biological Station" in 2008 (Michigan State University) and shows the extreme price differences for rhizomes in the US. It is never the less stated by [62] that, with rhizome prices decreasing to an European level through ongoing market maturity, cellulosic biomass from Miscanthus could become competitive with biomass from corn. In contrast, the very low price for rhizomes assumed by [20] is based on data gained from [22] where mechanical macro-propagation of rhizomes is assumed as a much cheaper alternative to the currently dominating in vitro micro-propagation of rhizomes. For further information about available propagation methods for Miscanthus rhizomes see e.g. [35, 81]. Figure 7 clearly shows that the costs for rhizomes represent the largest share of total establishment cost. When neglecting the above mentioned outliers, the mean per ha costs for rhizomes are $2074.95 €$ while the mean total establishment costs are $2575 € /$ ha. The average share of rhizome costs could therefore be estimated as around $80 \%$. Thus, rhizome costs are the most crucial factor in Miscanthus establishment, but they should be reducible by further research for advanced propagation methods. Total establishment costs further include costs of labor and machinery required for planting activities. These costs range from $66 € /$ ha in a Canadian study [72] to $455 € /$ ha in a study for the UK [49] with a mean (over 4 studies) of $423 € /$ ha. This amount of costs corresponds to $16 \%$ of total establishment costs. Some studies that examine establishment costs assume that specific machinery, necessary to cultivate Miscanthus, is provided by a contractor so that costs caused by machinery are covered by the payment for the contractor $[9,25,23]$ and no additional machinery has to be purchased. The

\footnotetext{
${ }^{11}$ Note, however, that the assumption of 10000 rhizomes per ha is by far the most common one.
} 
remaining $4 \%$ of costs are caused by establishment related maintenance such as weed control or fertilization and sum up to a mean of $112 € /$ ha. It is noteworthy that costs for replanting, although a replanting quota of up to $50 \%$ due to overwintering losses is indicated e.g. by [20] and [35], are usually not accounted for as establishment costs since they become due only in the second year or are even completely neglected.

\subsubsection{Closing the plantation}

Closing the plantation at the end of its lifetime also causes considerable costs between $77 € /$ ha [72] and $297 € /$ ha [10] with mean costs of $184.12 € /$ ha but as it only becomes necessary after 10 to 20 years, these costs are seen as less important from today's perspective. For instance, assuming a discount rate of $5 \%$, the $184 € /$ ha of costs for closing a plantation after $\mathrm{t}=20$ years imply a present value of $69 €$. Thus, the costs of closing of the plantation is actually not relevant from an economic point of view, i.e. does not affect the decision taken by the farmer to adopt Miscanthus.

\subsubsection{Annual Costs}

\subsubsection{Harvest}

Harvest costs play an important role since they account for the largest part of total annual costs. Miscanthus harvest can basically be carried out with standard farm equipment like corn harvesters and balers and is therefore assumed to be outsourced to a contractor as those machines are often too expensive to be maintained by single farms [25, 9, 23]. Costs for harvest vary due to different assumptions about processing methods such as chipping or mowing and baling $[30,72]$ and because of an inconsistency in the definition and calculation of harvest cost. While in some studies harvesting includes transport and/ or storage $[20,57$, 72] others only refer to the cost of cutting and baling or chipping $[20,48,56]$. Another barrier to comparability is the calculation of harvest costs whether on a per ha basis [20] or on a cost per weight basis [71]. When comparing harvest costs on a per ha basis it is important to account for the fact that the assumed per ha yield-level varies between the studies which may 
influence the assumed harvest cost. A specification of the average costs per unit of weight could therefore be helpful as well as an increased clarity concerning the components of the assumed harvest process. Figure 8 displays the range of harvest cost. The mean harvest cost per ha is $270.50 €$. Over all studies that report harvest costs and without considering the above mentioned inconsistencies, per ha harvest costs range from $37.09 €$ (only fix harvest costs per ha without baling and field transport) [71] to $724.05 €$ (including mowing, conditioning, ranking, swathing, baling, staging, loading and storage) [20]. These outliers are not displayed in Figure 8.

Figure 8: Mean harvest cost per ha.

Figure 8: Only those studies are included that provide harvest cost on a per ha basis $(n=17)$.

\subsubsection{Transport and Storage costs}

Costs for transport and storage may affect farm profits severely [37, 38, 69] but they are difficult to define and compare as they are strongly influenced by external factors such as transport distances, infrastructure conditions, volume and weight which in turn depend on the harvest process and the moisture content, the time period of storage, fuel prices etc. In addition, studies indicating costs for transport and storage are rare among the reviewed literature. Within those studies it is again problematic to compare costs for storage and transport on a per ha level [34] and on a per weight level [71]. Costs for transport are commonly stated as prices per oven dry ton (odt). They consist of a lump sum ranging from $0.99 €$ [37] to $5.76 €[48]$ per ton and an additional fee ranging from $0.06 €[15]$ to $0.36 €[49]$ per ton and $\mathrm{km}$ $(n=10)$. [30] provides an example on how the harvest process influences the costs for transport and storage: While chipping Miscanthus causes considerably lower harvest costs than baling, the subsequent transport costs are around $30 \%$ higher with $4.66 € / \mathrm{t}$ plus $0.21 € / \mathrm{t}$ and $\mathrm{km}$ compared to $3.69 €$ plus $0.16 € / \mathrm{t}$ and $\mathrm{km}$ [30]. Additionally, due to the larger volume, storage 
costs are higher for chipped than for baled Miscanthus with $88 € /$ ha compared to $38 € /$ ha [30]. The mean of the assumed transport distance over all reviewed paper addressing this aspect is $49 \mathrm{~km}(n=17)$. Data on storage costs are rarely provided in the studies examined $(n=8)$ and range from $21 € /$ ha [33] to $95 € /$ ha [34] or from 3.97€/t [71] to $6.79 € / t$ [34] also depending on factors like the harvest process as shown in the example. Further optimization of the production chain could help to reduce costs for transport and storage e.g. by establishing decentralized "down breaking" facilities as proposed by [82] and [83] to achieve higher value density of the materials.

\subsubsection{Fertilization, plant protection and weed control}

According to [22], weed control is only required in the establishment period and therefore limited to the first two years of cultivation. Moreover, only very few pests and diseases like Fusarium [84], Miscanthus Blight [85] and Barley Yellow Dwarf Luteovirus [86] are known to harm Miscanthus. In the examined literature Miscanthus is generally states as low labor intensive plant with low nutrient requirements affording fertilization once a year after harvest [20]. Still, there is no consensus concerning nutrient requirements of Miscanthus, especially concerning the yield response to nitrogen applications [25]. The assumptions made by [20] and [87] to apply $60 \mathrm{~kg} \mathrm{~N}$ per ha and year can therefore only be seen as a benchmark. Other annual cost factors e.g. overhead costs are comparable to conventional crops and thus no particularity of Miscanthus production.

\subsubsection{Opportunity costs of land and capital}

Finally, imputed costs, the opportunity costs of land and capital are considered as annual costs because the farmer, opting for Miscanthus, loses the opportunity to allocate land and capital to alternative uses each year again.

The costs of land are often not considered in literature [9, 30, 34] or assumed as the average regional land rent $[25,34], 66]$. What is mentioned as a reason against the assumption that average land rents should be regarded as costs of land is, that land rents actually do not reflect 
the average price but the maximum willingness to pay to get an additional part of land. Land rents can therefore be considered as the marginal costs of land [23]. In most of the examined studies e.g. $[15,20,23,51,72]$, the opportunity costs of land are considered as the "real" price of land because it is the loss of forgone revenues generated by alternative farm activities, that has to be overcome when opting for Miscanthus. Thus, the opportunity costs are mainly depending on the respective region and the potential alternatives to Miscanthus. Conclusively, when accounting for opportunity costs in a middle European setting, studies e.g. [44], [45], [9], [48] compare Miscanthus with wheat, barley, rapeseed, sugar beet or potatoes while in southern Europe also crops like tomatoes or cotton may play a dominant role [66]. In contrast, corn, soybean and wheat production are the major farming businesses Miscanthus has to compete with in North America [16], [71], [62], [37]. Hence it is obvious that the amount of opportunity costs cannot be stated in a general way. Growing Miscanthus on set aside land or on soils unsuitable for any other crop may cause very low opportunity costs while using highly productive farm land that could otherwise be used for special crops such as vegetables causes substantial opportunity costs. Insofar it is no surprise that only a minority $(n=8 ;[15,20,54,60$, 66, 70-72] ) report opportunity costs explicitly, although 23 studies generally mention, that opportunity costs play an important role in the decision whether to grow Miscanthus or not. Of those studies reporting opportunity costs, 7 use alternative crops as a reference. In the US and Canada, the most profitable alternative to Miscanthus is a corn-soybean rotation, applied by [20], [15], [72], [60] and [71] to calculate opportunity costs ranging, for instance, from $71 € / t$ for corn to $177 € / t$ for soybeans [20]. For Germany [70], assumed opportunity costs ranging from $441 € /$ ha for winter barley to $558 € /$ ha for winter wheat.

Further, the opportunity costs of capital have to be accounted for, since the capital bound to Miscanthus cultivation cannot be invested otherwise to gain revenues. To represent farmer's forgone revenues from alternative investment decisions as well as individual time preferences 
a discount rate has to be applied that reflects the time value of money ${ }^{12}$. In the reviewed literature the discount rates range from $4 \%$ [65] to $13 \%$ [52] with a mean of $5,8 \%$ and a median of $5 \%$ (Figure 9 ).

Figure 9: Discount rates

Figure 9: Total number of discount rates found in literature is $n=28$. Note that [52] states 5 different discount rates $(6,8,9,11$ and $13 \%)$ to consider e.g. future technology development. Other studies e.g. [10] and [25] do not report any discount rate with their results.

Most frequently a discount rate of $5 \%(n=9)$ is applied in literature. According to [62] the average rate of return on capital for US farms between 1960 and 2001 was $5 \%$ leading to a corresponding discount rate of $5 \%$ to represent the average farmers opportunity cost of capital.

\subsection{Benefits of Miscanthus cultivation}

\subsubsection{Yield assumptions}

Similar to other arable crops, Miscanthus yield is one of the most decisive factors directly influencing farmers' income. In order to provide potential adopters with reliable information about expectable annual yields, validated and reliable assumptions are required. This applies even more in the case of a perennial crop that causes high upfront establishment costs. These costs have to be recovered over a long period of time leading to a loss of cropping flexibility which hinders the farmer to react quickly on changing market conditions [9]. The source of uncertainty connected to crop yields is the possible deviation of real annual yields from the

\footnotetext{
12 This may not only account for costs of borrowed capital, opportunity costs of equity capital but also for the riskiness of the investment decision (e.g. [18]).
} 
expected potential yield. The higher this volatility, the higher is the uncertainty attached to Miscanthus yields. Given this assumption, it is remarkable that yield is considered as a stochastic factor when assessing the economics of Miscanthus only in 7 of the 51 studies [10, $16,32,45,61,66,70]$. If yield volatility is quantified, it is found to be large. For instance [45] and [56] report standard deviations of $2.9 \mathrm{t} / \mathrm{ha}$ and $2.94 \mathrm{t} / \mathrm{ha}$ leading to coefficients of yield variance of $22.7 \%$ and $23 \%$ respectively. Across the reviewed literature the standard deviation ranges from 1.64t/ha to 5.6t/ha (both [61]) leading to corresponding coefficients of variance of $12.6 \%$ to $29 \%{ }^{13}$. Thus, also yield variability can be a decisive risk component in the cultivation of Miscanthus cultivation. 8 additional articles state that yield volatility could be expected but do not quantify this statement $[15,30,38,40,41,67,71,72]$. While the assessment of yield volatility by means of statistical measures falls short in the reviewed literature the number of studies reporting assumptions about minimum and maximum yield expectations is higher with $\mathrm{n}=20$. Although assumptions on minimum and maximum yields give an impression of the potential range of yields, they may not be suitable as reliable yield indicators since they always represent extreme values that have to be considered in their respective context. For instance, [37] states a maximum expected yield level of $61 \mathrm{t} \mathrm{m} / \mathrm{ha}$ based on the assumption of high soil temperatures, high soil moisture and very few frost days in southern Illinois. That these optimal conditions are also very attractive to corn and soybean production making an adoption of Miscanthus in that area unlikely relativize those high Miscanthus yield assumptions. The range found in the examined studies between assumed minimum and maximum yields varies between 2.3t/ha in the UK [51] and 41t/ha in the US [15]. The wide range of yield expectations in the latter case results from the high diversity of examined planting sites concerning the type of soil, temperature or moisture etc. which again indicates the requirement of fertile locations

\footnotetext{
${ }^{13}$ Note that this relative variability of crop yields is high if compared with annual crops, where this production risk is known for a long time to be decisive for resource use decisions by farmers (e.g. [88], [89])
} 
for Miscanthus in order to generate highest yields. This is also supported by [45], while [16] states that growing Miscanthus on productive soils which are suitable for corn or soybeans is not a viable alternative due to high opportunity costs. Supporting the opinion of [16], studies [15], [69] and [40] recommend the adoption of Miscanthus on sites which are rather inappropriate for conventional crops e.g. due to eroded soils. The availability of arable land with low soil qualities may therefore be seen as factor driving farmers' decision towards the adoption of Miscanthus. This again shows the relevance of the trade-offs between high returns from Miscanthus cultivation and the opportunity costs associated with this planting decision in form of forgone revenues from other land use activities.

Figure 10 summarizes the assumptions found in literature concerning mean Miscanthus yields differentiated by region, standard deviations and the corresponding coefficients of variation.

Figure 10: Mean Miscanthus yields, standard deviations and coefficients of variation

Figure 10: Mean Yield: EU: $n=21$; North America: $n=13$; standard deviation: $n=12$; coefficient of variation (own calculation): $n=12$. Note that [32] and [61] reported 2 and 3 assumptions on standard deviations respectively to account for different scenarios of uncertainty.

\subsubsection{Prices}

The single farmer is usually described as price taker which means he adjusts the production quantity to a market price which he cannot influence [90]. Two observations are common to many studies. First, there is no reliable "market price" for Miscanthus available as benchmark as there is only a very undeveloped market for Miscanthus existing [48, 54, 60]. Second, current Miscanthus prices assumed in literature are often too low to make Miscanthus a competitive alternative to conventional crops [43-45]. Figure 12 shows the broad range in average price assumptions made in the examined literature. A key problem is the difference of price relations used in literature. Prices were given relative to energy content or relative to 
a unit of weight and depending on the processing. Without information about the assumed moisture and energy content, problems arise in generating comparable data. To ensure consistent representation of prices we thus focus in figure 11 on prices that are related to weight in tons dry matter.

Figure 11: Mean Miscanthus prices differentiated by region

Figure 11: EU: $n=18$; North America: $n=13$

Price assumptions stated in the reviewed literature range from $48.56 € / \mathrm{t} d \mathrm{~m}$ [15] to $134 € / \mathrm{t} \mathrm{dm}$ [52] [36]. Assumptions on mean prices range from $48.56 € / \mathrm{t} \mathrm{dm} \mathrm{[15]} \mathrm{to} 108 € / \mathrm{t} \mathrm{dm}$ [52]. Reflecting volatilities on energy markets (e.g. the fossil fuel market), high price uncertainties should be expected in the case of Miscanthus. However, many studies do not consider price volatility when assessing the profitability of Miscanthus. [62] and [56] for example are considering different price scenarios for Miscanthus in their models but only 7 out of the 51 examined studies assess the influence of price volatility on the profitability of Miscanthus by means of stochastic modelling. For instance, [10] assumes Miscanthus prices being normally distributed around a stochastic time trend and uses them as input variables in the modified Monte Carlo simulation Repetitive Latin Hypercube sampling. A similar approach is conducted by [67] where prices are supposed to follow a normal distribution. Due to a lack of historic data for energy crops, [67] assumes Miscanthus prices to show the same volatility as wheat prices. Thus, a coefficient of variation of $15 \%$ and $35 \%$ is applied as measure of volatility in a low and a high price-volatility scenario assuming a mean Miscanthus output price of $70 € /$ t.

The general avoidance concerning the consideration of price uncertainty may be due to a lack of reliable price data which is caused by the relative novelty of the crop, considerable regional variation in yield potential and production costs and the lack of an established market that 
could otherwise offer easy access to information [16, 72]. Thus, giving reliable estimations on Miscanthus prices is challenging. A solution for potential adopters to cope with price variability and uncertainty could be the production of Miscanthus based on contracts with e.g. energy suppliers. Binding prices and secure demand negotiated with contract partners is thus seen as a key factor, besides attractive establishment grants, to accelerate Miscanthus production by e.g. [45], [43, 48, 52, 68]. Overall, in 10 studies contracts offering guarantee prices leading to a risk sharing between producer and demander of Miscanthus are seen as prerequisite for Miscanthus adoption [48], [56, 67], [23]. More research should therefore be undertaken concerning the optimal design and influences of contracts in Miscanthus production

Instead of assuming a market price 11 studies [15, 20, 32, 36, 55, 61, 62, 65, 71-73] calculate the breakeven price of Miscanthus production in order to identify the minimum required or the maximum achievable market price. For the calculation of the break-even price, two different approaches are applied in the examined studies: For instance, [15], [20], [62] and [61] calculate a "comparative breakeven price" which not only covers production costs of Miscanthus but also the forgone profits of alternative crops such as corn or soybean to find the minimum price that a farmer would demand for growing Miscanthus. Another approach can be found in studies were the competitiveness of Miscanthus relative to coal as a combustion material is assessed. Here, Miscanthus not only has to compete with other crops but also with fossil energy carriers. In this case not the breakeven price of Miscanthus necessary to cover all production costs is calculated but the price of Miscanthus which is required to break even with coal prices based on its respective energy content. This price is then compared to the production costs of Miscanthus with the result, that costs of biomass production can be competitive under certain circumstances [72] but are usually higher than its market value based on the energy content and the price of fossil energy carriers [20], [32]. Thus, prices for fossil fuels are a major determinant of the profitability of Miscanthus. Since this review does not focus on utilization pathways of Miscanthus but on its cultivation, a large amount of literature dealing with the competitiveness of Miscanthus with regards to its' calorific 
value has been excluded during the review process ${ }^{14}$ and is therefore not presented here. Break-even prices found in literature range from the minimum of $36 € / t[37,37]$ to a maximum of $284 € / t$ [36] with a mean of $76.11 € / t$. The low break-even price calculated by [37] results from the fact that opportunity cost are not considered in this case. Taking into account opportunity costs of land, the break-even costs assumed by [37] rise to $51.21 € /$ t. When comparing the average mean "market" prices and the average mean breakeven prices it turns out that the mean Miscanthus breakeven price is in average slightly higher with $76.11 € / t$ than the mean Miscanthus "market" price with $72.82 € /$ t. Although the underlying dataset cannot claim representativeness this could indicate that at current ratio of production costs to selling price production might not be profitable. However the difference between mean output price and mean breakeven price is only $3.30 €$ and strongly influenced by the small data sample. Nevertheless, additional research and increased practical experience in Miscanthus cultivation could be helpful to lower the break-even costs which would make Miscanthus a more competitive source of biomass.

\subsubsection{Subsidies}

In 20 of the considered studies ${ }^{15}$, policies to promote biomass production and/ or utilization are regarded as requirement to adopt Miscanthus and/ or to enhance the competitiveness of Miscanthus compared to alternative crops or resources. Establishment subsidies are seen as one of the most crucial preconditions for farmers to opt for Miscanthus cultivation. Some papers state that without the availability of substantial establishment grants, farmers are unlikely to adopt Miscanthus facing the above mentioned high initial costs [44, 45]. In the UK, the "Energy Crop Scheme" provides establishment grants of up to $50 \%$ or a certain fix amount of money to facilitate the adoption of Miscanthus. In detail, the subsidization ranges between a refund of $40 \%$ [52] to $50 \%$ [50] of the establishment costs or, alternatively an establishment

\footnotetext{
${ }^{14}$ For more information about the calorific value of Miscanthus see e.g. [91]

15 Those are in detail : $[16,20,23,32,33,37,38,40,44,45,47-51,58,59,61,64,65]$
} 
subsidy of $938 € /$ ha [48] to $1072 € /$ ha [49]. A similar program is offered in Ireland, called "Bioenergy Scheme", offering a refund of $50 \%$ of establishment costs or up to $1295 € /$ ha [57] to $1450 € /$ ha [54]. Additionally there is an EU wide energy crop premium available of $45 € /$ ha per year [66, 68], [23]. In the US, the "Biomass Crop Assistance Program" (BCAP) offers support for biomass production but the considered implementation differs within the literature. Studies [60] and [37] assume that farmers are paid additional 40-45€/t of Miscanthus, which only applies for a period of 2 years in the case of [60]. In contrast, [16] assumes that the BCAP offers an establishment grant of $75 \%$ of the initial costs plus additional $20 € /$ ha and year to support Miscanthus producers. Another form of government intervention to promote biomass for energy production is indirect subsidization, which serves to improve the competitiveness of biomass prices compared to fossil fuel prices. One of those measures demanded in literature e.g. by [32] and [20] is the taxation of carbon emissions caused by the combustion of fossil fuels. For example, [65] calculates a carbon tax of $15.8 € / t$ of $\mathrm{CO}_{2}$ emitted by coal firing plants necessary to make Miscanthus competitive with coals for energy production. Other approaches for Miscanthus promotion mentioned in literature are mandatory co-firing with coals in power plants [32] and a monetization of ecosystem services provided by Miscanthus like sequestration of carbon in the soil, protection against erosion, waste water treatment, removal of heavy metals or increased biodiversity in order to reward the farmer for providing these public goods [20], [23], [24], [25]. When comparing the area planted with Miscanthus in the UK with the area in other European countries like Germany, where no corresponding subsidies are available it seems as if subsidization of establishment costs is suitable to motivate farmers for Miscanthus adoption. According to [92] 10000 ha are currently planted with Miscanthus in the UK while in Germany less than half the area (4500 ha) is committed to Miscanthus cultivation. There are certainly additional factors like socio-economic characteristics e.g. the age or the education of farmers that may also influence the farming decision [24], [41], which makes it difficult to distinguish exactly between the effects caused by policy measures and those effects stimulated by other factors. Thus, the impact of subsidies on the farming decision concerning Miscanthus should be subject to further research. 
Especially the efficiency of subsidization measures with regard to partly contradicting policy targets like climate protection and energy supply security should be further assessed. Furthermore, it is important to mention that also the reduction of opportunity costs can contribute to the profitability of perennial bioenergy crops by reducing the extend to what these crops have to compete with other crops. For example, [66] assessed the potential impact of the 2003 CAP reform ("decoupling" of agricultural payments, introduction of "crosscompliance" etc. [93]) on the amount of biomass production. According to [66], decoupled subsidies payed to farmers which are not devoted to a certain "conventional" crop lead to strongly decreased opportunity costs of biomass production. Under ceteris paribus conditions, these payments thus have a positive effect on the competitiveness of Miscanthus compared to other crops and concerning the adoption decision of farmers.

A more recent example for agricultural policies which could have an opportunity costs decreasing effect is the so-called "Greening" of the CAP, where farmers have to use $5 \%$ of their land as Ecological Focus Area (EFA) in order to receive some part of the direct payments [94]. While short rotation coppice can be accounted for as EFA (with a factor of 0.3 ), cropping Miscanthus however is not considered as potential contribution to these ecological focus areas. By that, Miscanthus is indirectly discriminated although research has already indicated that Miscanthus may contribute significantly to ecosystem services like

increasing biodiversity ${ }^{16}$ compared to conventional crop rotations (through reduced application of agro-chemicals, reduced soil preparation and a harvest date in spring, offering cover for

\footnotetext{
${ }^{16}$ To measure beneficial effects of Miscanthus on biodiversity and soil carbon sequestration, the studies we reviewed compare Miscanthus to conventional, more intensive cultivation practices (see
} 
wildlife during winter), waste water treatment or carbon sequestration (e.g. [20], [23], [24], $[25])^{17}$. To what extent these services (especially soil carbon sequestration and benefits for biodiversity) are relevant should be subject to further research. Adjusting current agricultural and environmental policies with regard to the benefits of Miscanthus would, c.p. increase the relative competitiveness of Miscanthus production.

\section{Shortcomings in literature and implications for future research}

A comprehensive assessment of the general profitability of Miscanthus is difficult due to the diverse nature of the underlying data sample gained from the reviewed literature. For instance, we found large variety of different directions of research found in literature with the consequence of a high diversity in underlying assumptions and applied research methods. Considering Miscanthus cultivation as a business which is strongly affected by especially price and yield risks, leading to uncertain future cash-flows, it is surprising, that dynamic budgeting methods which do not account for uncertainty are preferred in the examined literature ${ }^{18}$.

In this context, the reluctance of authors with regard to the consideration of price and yield volatility is noticeable but can be assumed to result from a lack of historic yield and price data. To ameliorate the consideration of risk in future research dealing with the profitability of Miscanthus, budgeting methods taking into account uncertainty should be chosen instead of more simply applicable but unsophisticated dynamic approaches like discounted cash flow analysis. To enable further a more precise comparison of prices and costs across the

also Table 1 for the reference systems chosen in the reviewed studies). Compared to native, untouched nature or even semi-natural forests, biodiversity provided by Miscanthus plantations is low. ${ }_{17}$ More general, any form of support for other (food or non-food) forms of land use ceteris paribus reduces the attractiveness of Miscanthus.

${ }^{18}$ Along these lines, it is important to highlight that extension services addressing practitioners might even not fully take the step towards dynamic consideration of periodical cash-flows, but focus on the misleading perspective of static contribution margins (e.g. [95]) 
literature, consistent measurements should be applied. Prices were found to be related to the energy content or to their mass measured in tons dry matter or in oven dry tons. A similar problem applies to costs of Miscanthus production which were found to be stated on a per hectare as well as on a per ton basis. A consistent measurement system including information about the assumed energy and moisture contents could be helpful to enhance the reliability of price and costs estimations. Additionally, across the examined studies, data are not reported accordingly thus leading to a lack of information in some parts e.g. regarding different cost items of cultivating Miscanthus such as costs of planting activities or costs of maintenance. While some papers are describing their assumed costs very precisely considering every single step of Miscanthus cultivation like spraying, ploughing, planting etc. [20], others only report the total costs of all these activities together or in some cases they do not report any underlying assumption. Another example for incompleteness in the underlying assumptions can be found in a number of studies that analyses discounted future cash flows, but do not report the underlying discount rate. A similar problem can be found with regard to the reference system of Miscanthus where $25 \%$ of the examined papers do not mention any alternative crop to be compared with Miscanthus in order to assess its profitability. Further, in this context, 4 papers compare the profitability of growing Miscanthus with src but do not mention which kind if src cultivar is assumed, although considerable differences in the economics of src crops have been observed (e.g. [6]). Those lacks of transparency make it difficult to follow the calculations and conclusions stated in some papers. Since Miscanthus is still a rather novel and unexplored crop a lack of reliable and consistent data may need to be accepted, but also proves the necessity of intensive research for more trusted information about prices, yields, costs and cultivation of Miscanthus. It can also be assumed that further agronomic research, may be dealing with other breeds of Miscanthus than only Miscanthus $x$ Giganteus, will lead to improved exploitation of currently unutilized potentials. Furthermore, a shortcoming identified in the examined studies is the strictly one-sided consideration of Miscanthus as source of bioenergy while other potential applications which might allow higher sales prices and thus 
higher farm incomes remain completely untouched and should therefore be subject to future research.

\section{Conclusion}

In this article we assessed and reviewed information gained from 51 scientific studies in order to increase the knowledge concerning the economics of Miscanthus cultivation and to reveal and illustrate the factors influencing the adoption decision of farmers to provide future research and agricultural consultancy with key information and a solid data basis.

The factors that have been identified as being most critical for the profitability of Miscanthus and thus for the adoption decision of the farmer are diverse in their nature. More specifically, the expected lifespan, biomass yields, prices, establishment and opportunity costs and subsidization possibilities are crucial for the profitability of Miscanthus and therefore seen as decisive factors for potential Miscanthus adopters.

Moreover, our review revealed large uncertainty especially concerning the key parameters yields and prices. Across all studies, mean yield assumptions were found to range from 10 to $48 \mathrm{tdm} /$ ha while the assumptions concerning mean prices range from 48 to $134 € / \mathrm{tdm}$.

This indicates the need for further research in order to ensure more homogeneous assumptions on agronomic aspects (e.g. biomass yields, productive lifespan of Miscanthus, or rhizome costs etc.) as well as the application of more elaborate economic assessment methods, since static and even dynamic approaches which were mostly found in literature are not suitable to capture uncertainty involved in Miscanthus production. Our review revealed that, even though risks associated with the long-term commitment of Miscanthus production seem to be a major determinant for the adoption reluctance of farmers, only a limited number of studies addresses this explicitly, showing however that substantial variability in prices, yields and costs etc. can be expected.

As the assessment of bioenergy policies is not in the center of interest of this review, a deeper investigation of different national and transnational policies promoting different kinds of biomass could bring up more sophisticated results. Special emphasis should be placed on the 
optimal design of policies aiming at promoting the cultivation of Miscanthus and comparable perennial biomass crops. Further, as the absence of an established market for biomass is mentioned as major impediment leading to increased market risks, future research should focus on the potential to foster the adoption of Miscanthus by providing risk minimization to adopters e.g. by means of contracting and/ or insurance solutions.

The great heterogeneity in assumptions, regarded regions, reference systems etc. do not allow a final and general statement concerning the profitability of Miscanthus as it always depends on individual aspects such as regional demand, the availability of subsidies or opportunity costs. Nevertheless this review paper provides a valuable overview about the most crucial factors influencing Miscanthus adoption which may help to encourage further research efforts and underlines the high but still unexploited potential of Miscanthus to contribute to future (energy) needs. Due to its relative novelty, Miscanthus and its cultivation is likely to be further developed through agronomical and (bio-) technological research, leading to improved yields and technical characteristics as well as reduced production costs [25] .

\section{Acknowledgements}

We would like to thank the editor and three anonymous reviewers for helpful comments on an earlier version of this paper. Furthermore, we would like to thank Felix Winzer, Thorsten Kraska and Ralf Pude for their valuable inputs and the fruitful discussions on various aspects of Miscanthus cultivation. This work was supported by the Bioeconomy Science Center in the white paper project "MisCas". The scientific activities of the Bioeconomy Science Center were financially supported by the Ministry of Innovation, Science and Research within the framework of the NRW Strategieprojekt BioSC (No. 313/323-400-002 13).

\section{References}

[1] Jacobson MZ. Review of solutions to global warming, air pollution, and energy security. Energy \& Environmental Science 2009;2(2):148-73. 
[2] German Advisory Council on Global Change. Factsheet No. 2/2011; Transforming Energy Systems. [November 19, 2014]; Available from:

http://www.wbgu.de/fileadmin/templates/dateien/veroeffentlichungen/factsheets/fs2011fs2/WBGU_FS2_2011_Energie_en.pdf.

[3] Beringer T, Lucht W, Schaphoff S. Bioenergy production potential of global biomass plantations under environmental and agricultural constraints. GCB Bioenergy 2011;3(4):299-312.

[4] Gustavsson L, Börjesson P, Johansson B, Svenningsson P. Reducing CO2 emissions by substituting biomass for fossil fuels. Energy 1995;20(11):1097-113.

[5] The Publications Office of the European Union. Directive 2009/28/ec of the European parliament and of the council of 23 april 2009 on the promotion of the use of energy from renewable sources and amending and subsequently repealing directives 2001/77/ec and 2003/30/ec. [November 19, 2014]; Available from: http://eurlex.europa.eu/legal-content/DE/TXT/PDF/?uri=CELEX:32009L0028\&from=EN.

[6] Faasch RJ, Patenaude G. The economics of short rotation coppice in Germany. Biomass and Bioenergy 2012;45:27-40.

[7] European Commission. Renewable Energy Statistics - Statistics Explained. [November 19, 2014]; Available from:

http://epp.eurostat.ec.europa.eu/statistics_explained/index.php/Renewable_energy_sta tistics.

[8] Fachagentur Nachwachsende Rohstoffe e.V. Miscanthus. [November 19, 2014]; Available from: http://bioenergie.fnr.de/heizen-mit-holz/miscanthus/.

[9] Styles D, Thorne F, Jones MB. Energy crops in Ireland: An economic comparison of willow and miscanthus production with conventional farming systems. Biomass and Bioenergy 2007;32(5):407-21.

[10] Clancy D, Breen JP, Thorne F, Wallace M. A stochastic analysis of the decision to produce biomass crops in Ireland. Biomass and Bioenergy 2012;46:353-65. 
[11] Asif M, Muneer T. Energy supply, its demand and security issues for developed and emerging economies. Renewable and Sustainable Energy Reviews 2007;11(7):1388413.

[12] FAO, Food and Agriculture Organization of the United Nations. FaoStat. [May 04, 2015]; Available from: http://faostat3.fao.org/compare/E.

[13] FAO, Food and Agriculture Organization of the United Nations. State of the world's forests 2014: Enhancing the socioeconomic benefits from forests. Rome; 2014.

[14] Dolginow JP, Massey RE. Switchgrass and miscanthus: economics of perennial grasses grown for bioenergy. University of Missouri, Office of Extension 2013.

[15] Jain AK, Khanna M, Erickson M, Huang H. An integrated biogeochemical and economic analysis of bioenergy crops in the midwestern United States. GCB Bioenergy 2010;2(5):217-34.

[16] Dolginow J, Massey RE, Kitchen NR, Myers DB, Sudduth KA. A stochastic approach for predicting the profitability of bioenergy grasses. Agronomy Journal 2014;106(6):2137.

[17] Ridier A. Farm level supply of short rotation woody crops: economic assessment in the long-term for household farming systems. Canadian Journal of Agricultural EconomicsRevue Canadienne d'Agroeconomie 2012;60(3):357-75.

[18] Musshoff O. Growing short rotation coppice on agricultural land in Germany: a real options approach. Biomass and Bioenergy 2012;41:73-85.

[19] Fazio S, Barbanti L. Energy and economic assessments of bio-energy systems based on annual and perennial crops for temperate and tropical areas. Renewable Energy 2014;69:233-41.

[20] Khanna M, Dhungana B, Clifton-Brown J. Costs of producing miscanthus and switchgrass for bioenergy in Illinois. Biomass and Bioenergy 2008;32(6):482-93.

[21] Zhu X, Long SP, Ort DR. What is the maximum efficiency with which photosynthesis can convert solar energy into biomass? Current opinion in biotechnology 2008;19(2):153-9. 
[22] Lewandowski I, Clifton-Brown JC, Scurlock J, Huisman W. Miscanthus: European experience with a novel energy crop. Biomass and Bioenergy 2000;19(4):209-27.

[23] Ericsson K, Rosenqvist H, Nilsson LJ. Energy crop production cost in the EU. Biomass and Bioenergy 2009;33(11):1577-86.

[24] Cope MA, McLafferty S, Rhoads BL. Farmer attitudes toward production of perennial energy grasses in east central Illinois: implications for community-based decision making. Annals of the Association of American Geographers 2011;101(4):852-62.

[25] Smeets EM, Lewandowski IM, Faaij AP. The economical and environmental performance of miscanthus and switchgrass production and supply chains in a European setting. Renewable and Sustainable Energy Reviews 2009;13(6-7):1230-45.

[26] Gerbens-Leenes PW, Hoekstra AY, van der Meer Th. The water footprint of energy from biomass: a quantitative assessment and consequences of an increasing share of bio-energy in energy supply. Ecological Economics 2009;68(4):1052-60.

[27] Stöglehner G. Ecological footprint - a tool for assessing sustainable energy supplies. Journal of Cleaner Production 2003;11(3):267-77.

[28] Heaton EA, Long SP, Voigt TB, Jones MB, Clifton-Brown J. Miscanthus for renewable energy generation: European Union experience and projections for Illinois. Mitigation and Adaptation Strategies for Global Change 2004;9(4):433-51.

[29] Huisman W, Venturi P, Molenaar J. Costs of supply chains of miscanthus giganteus. Industrial Crops and Products 1997;6(3-4):353-66.

[30] Venturi P, Gigler JK, Huisman W. Economical and technical comparison between herbaceous (miscanthus $x$ giganteus) and woody energy crops (salix viminalis). Renewable Energy 1999;16(1-4):1023-6.

[31] Heaton EA, Dohlemann FG, Long SP. Meeting US biofuel goals with less land: the potential of miscanthus. Global Change Biology 2008;14(9):2000-14.

[32] Aravindhakshan SC, Epplin FM, Taliaferro CM. Economics of switchgrass and miscanthus relative to coal as feedstock for generating electricity. Biomass and Bioenergy 2010;34(9):1375-83. 
[33] Spicer MR, Fagan CC, Ward S, McDonnell K. Economic assessment of commercial biofuel production in Ireland. Energy sources part b-economics planning and policy 2012;7(1):10-20.

[34] Krasuska E, Rosenqvist H. Economics of energy crops in Poland today and in the future. Biomass and Bioenergy 2012;38:23-33.

[35] Clifton-Brown JC, Lewandowski I. Overwintering problems of newly established miscanthus plantations can be overcome by identifying genotypes with improved rhizome cold tolerance. New Phytologist 2000;148(2):287-94.

[36] Vavrova K, Knapek J. Economic assessment of miscanthus cultivation for energy purposes in the Czech Republic. Journal of the Japan Institute of Energy 2012;91(6):485-94.

[37] Scheffran J, BenDor T. Bioenergy and land use: a spatial-agent dynamic model of energy crop production in Illinois. International Journal of Environment and Pollution 2009;39(1-2):4-27.

[38] Thomas A, Bond A, Hiscock K. A GIS based assessment of bioenergy potential in England within existing energy systems. Biomass and Bioenergy 2013;55:107-21.

[39] Diamantidis ND, Koukios EG. Agricultural crops and residues as feedstocks for nonfood products in western Europe. Industrial Crops and Products 2000;11(2-3):97-106.

[40] van der Hilst F, Dornburg V, Sanders J, Elbersen B, Graves A, Turkenburg WC et al. Potential, spatial distribution and economic performance of regional biomass chains: the north of the Netherlands as example. Agricultural Systems 2010;103(7):403-17.

[41] Bocquého G, Jacquet $F$, Reynaud A. Determinants of miscanthus adoption: an empirical investigation among French farmers. Paper submitted to the 5th "Journées de recherches en sciences sociales" in Dijon, France, December 8th-9th 2011.

[42] Clancy D, Breen J, Butler AM, Thorne F, Wallace M. Valuing the risk associated with willow and miscanthus relative to conventional agricultural systems. Paper submitted to the international congress of the "European association of agricultural economists" in Ghent, Belgium, August 26th-29th 2008. 
[43] Clancy D, Breen J, Buttler AM, Thorne F. The economic viability of biomass crops versus conventional agricultural systems and its potential impact on farm incomes in Ireland. Paper submitted to the 12th congress of the "European association of agricultural economists" in Sevilla, Spain, January 29th-February 1st 2008.

[44] Sherrington C, Bartley J, Moran D. Farm-level constraints on the domestic supply of perennial energy crops in the UK. Energy Policy 2008;36(7):2504-12.

[45] Alexander P, Moran D. Impact of perennial energy crops income variability on the crop selection of risk averse farmers. Energy Policy 2013;52:587-96.

[46] Tate G, Mbzibain A, Ali S. A comparison of the drivers influencing farmers' adoption of enterprises associated with renewable energy. Energy Policy 2012;49(0):400-9.

[47] Alexander P, Moran D, Rounsevell M, Hillier J, Smith P. Cost and potential of carbon abatement from the UK perennial energy crop market. GCB Bioenergy 2014;6(2):15668.

[48] Sherrington C, Moran D. Modelling farmer uptake of perennial energy crops in the UK. Energy Policy 2010(38):3567-78.

[49] Wang S, Wang S, Hastings A, Pogson M, Smith P. Economic and greenhouse gas costs of miscanthus supply chains in the United Kingdom. GCB Bioenergy 2012;4(3):358-63.

[50] Alexander P, Moran D, Smith P, Hastings A, Wang S, Suennenberg G et al. Estimating UK perennial energy crop supply using farm-scale models with spatially disaggregated data. GCB Bioenergy 2014;6(2):142-55.

[51] Bauen AW, Dunnett AJ, Richter GM, Dailey AG, Aylott M, Casella E et al. Modelling supply and demand of bioenergy from short rotation coppice and miscanthus in the UK. Bioresource Technology 2010;101(21):8132-43.

[52] Alexander P, Moran D, Rounsevell M, Smith P. Modelling the perennial energy crop market: the role of spatial diffusion. Journal of The Royal Society/ Interface 2013;10(88). 
[53] Glithero NJ, Wilson P, Ramsden SJ. Prospects for arable farm uptake of short rotation coppice willow and miscanthus in England. Applied energy 2013;107(100):209-18.

[54] Clancy D, Breen J, Butler AM, Thorne F, Wallace M. A discounted cash flow analysis of financial returns from biomass crops in Ireland. Journal of Farm Management;13(9):117.

[55] Deverell R, McDonnell K, Ward S, Devlin G. An economic assessment of potential ethanol production pathways in Ireland. Energy Policy 2009;37(10):3993-4002.

[56] Clancy D, Breen J.P., Thorne F, Wallace M. The influence of a renewable energy feed in tariff on the decision to produce biomass crops in Ireland. Energy Policy 2012;41(0):412-21.

[57] Zimmermann J, Styles D, Hastings A, Dauber J, Jones MB. Assessing the impact of within crop heterogeneity ('patchiness') in young miscanthus $\mathrm{x}$ giganteus fields on economic feasibility and soil carbon sequestration. GCB Bioenergy 2014;6(5):566-76.

[58] Augustenborg CA, Finnan J, McBennett L, Connolly V, Priegnitz U, Müller C. Farmers' perspectives for the development of a bioenergy industry in Ireland. GCB Bioenergy 2012;4(5):597-610.

[59] Clancy D, Breen J, Moran D, Thorne F, Wallace M. Examining the socio-economic factors affecting willingness to adopt bioenergy crops. Journal of International Farm Management 2011;4(5).

[60] Shastri Y, Rodriguez L, Hansen A, Ting KC. Agent-based analysis of biomass feedstock production dynamics. Bioenergy Research 2011;4(4):258-75.

[61] Huang HX, Khanna M, Booth E, Halford N, Shield I, Taylor G et al. The breakeven costs of alternative feedstocks for cellulosic biofuels. Aspects of Applied Biology 2011(112):153-62.

[62] James LK, Swinton SM, Thelen KD. Profitability analysis of cellulosic energy crops compared with corn. Agronomy Journal 2010;102(2):675-87. 
[63] Villamil MB, Silvis AH, Bollero GA. Potential miscanthus' adoption in Illinois: information needs and preferred information channels. Biomass and Bioenergy 2008;32(12):133848.

[64] Villamil MB, Alexander M, Silvis AH, Gray ME. Producer perceptions and information needs regarding their adoption of bioenergy crops. Renewable and Sustainable Energy Reviews 2012;16(6):3604-12.

[65] Khanna M, Oenal H, Dhungana B, Wander M. Economics of herbaceous bioenergy crops for electricity generation: implications for greenhouse gas mitigation. Biomass and Bioenergy 2011;35(4):1474-84.

[66] Lychnaras V, Schneider UA. Multi-farm economic analysis of perennial energy crops in central Greece, taking into account the CAP reform. Biomass and Bioenergy $2011 ; 35(1): 700-15$.

[67] Bocquého G, Jacquet $F$. The adoption of switchgrass and miscanthus by farmers: impact of liquidity constraints and risk preferences. Energy Policy 2010;38(5):2598607.

[68] Simon D, Tyner WE, Jacquet F. Economic analysis of the potential of cellulosic biomass available in France from agricultural residue and energy crops. Bioenergy Research 2010;3(2):183-93.

[69] Rizzo D, Martin L, Wohlfahrt J. Miscanthus spatial location as seen by farmers: a machine learning approach to model real criteria. Biomass and Bioenergy 2014;66:348-63.

[70] Wolbert-Haverkamp M. Miscanthus and poplar plantations in short rotation as an alternative to classical crop husbandry - a risk analysis by means of Monte Carlo simulation. Berichte über Landwirtschaft 2012;90(2):302-16.

[71] Laporte AV de, Weersink AJ, McKenney DW. A spatial model of climate change effects on yields and break-even prices of switchgrass and miscanthus in Ontario, Canada. GCB Bioenergy 2014;6(4):390-400. 
[72] Vyn RJ, Virani T, Deen B. Examining the economic feasibility of miscanthus in Ontario: an application to the greenhouse industry. 50 / 1. Energy Policy 2012:669-76.

[73] Hu M, Lin C, Chou C, Hsu S, Wen T. Analysis of biomass co-firing systems in Taiwan power markets using linear complementarity models. Energy Policy 2011;39(8):4594600.

[74] Weber JA. More than a farm bill: food, conservation, and energy act of 2008. Journal of the American Dietetic Association 2008;108(9):1428-32.

[75] Hauk S, Knoke T, Wittkopf S. Economic evaluation of short rotation coppice systems for energy from biomass-a review. Renewable and Sustainable Energy Reviews $2014 ; 29(0): 435-48$.

[76] lakovou E, Karagiannidis A, Vlachos D, Toka A, Malamakis A. Waste biomass-toenergy supply chain management: a critical synthesis. Waste Management 2010;30(10):1860-70.

[77] Amon T, Amon B, Kryvoruchko V, Zollitsch W, Mayer K, Gruber L. Biogas production from maize and dairy cattle manure-influence of biomass composition on the methane yield. Agriculture, Ecosystems \& Environment 2007;118(1-4):173-82.

[78] Aust J, Bachmann G, Pecenka R. Energieholz aus kurzumtriebsplantagen leitfaden für produzenten und nutzer im land Brandenburg. [April 27, 2015]; Available from: www.etibrandenburg.de/fileadmin/user_upload/downloads_2013/KUP_Leitfaden_2013_lowres. pdf.

[79] Dufossé K, Drewer J, Gabrielle B, Drouet J. Effects of a 20-year old miscanthus × giganteus stand and its removal on soil characteristics and greenhouse gas emissions. Biomass and Bioenergy 2014;69:198-210.

[80] Clifton-Brown J, Breuer J, Jones M. Carbon mitigation by the energy crop, miscanthus. Global Change Biology 2007;13(11):2296-307.

[81] Atkinson CJ. Establishing perennial grass energy crops in the UK: a review of current propagation options for miscanthus. Biomass and Bioenergy 2009;33(5):752-9. 
[82] Trippe F, Fröhling M, Schultmann F, Stahl R, Henrich E. Techno-economic assessment of gasification as a process step within biomass-to-liquid (BtL) fuel and chemicals production. Fuel Processing Technology 2011;92(11):2169-84.

[83] Trippe F, Fröhling M, Schultmann F, Stahl R, Henrich E, Dalai A. Comprehensive techno-economic assessment of dimethyl ether (DME) synthesis and fischer-tropsch synthesis as alternative process steps within biomass-to-liquid production. Fuel Processing Technology 2013;106:577-86.

[84] Thinggaard K. Study of the role of fusarium in the field establishment problem of miscanthus. Acta Agriculturae Scandinavica, Section B - Soil \& Plant Science $1997 ; 47(4): 238-41$.

[85] O'Neill NR., Farr DF. Miscanthus blight, a new foliar disease of ornamental grasses and sugarcane incited by leptosphaeria sp. and its anamorphic state stagonospora sp. Plant disease 1996;80(9):980-7.

[86] Christian DG, Lamptey JN, Forde SM, Plumb RT. First report of barley yellow dwarf luteovirus on Miscanthus in the United Kingdom. European Journal of Plant Pathology 1994;100(2):167-170.

[87] Clifton-Brown JC, Lewandowski I. Screening miscanthus genotypes in field trials to optimize biomass yield and quality in southern Germany. European Journal of Agronomy 2002;16(2):97-110.

[88] Just RE. An investigation of the importance of risk in farmers' decisions. American Journal of Agricultural Economics 1974;56(1):14.

[89] Chavas J. Risk analysis in theory and practice. 1st ed. Amsterdam, Boston: Elsevier Butterworth-Heinimann; 2004.

[90] Wiggerthale M, Strickner A. Bauern oder Lebensmittelunternehmen - wer hat das sagen? Marktkonzentration und ihre Auswirkungen auf den Agrar- und Nahrungsmittelsektor und die Politik in der EU. [March 12, 2015]; Available from: http://www.google.de/url?sa=t\&rct=j\&q=\&esrc=s\&source=web\&cd=1\&ved=0CCEQFjAA \&url=http\%3A\%2F\%2Fwww.beigewum.at\%2Fwordpress\%2Fwp- 
content\%2Fuploads\%2F2008_3_032-

38.pdf\&ei=ilo_VYnIDoK7OP_KgJgN\&usg=AFQjCNE7AEBk3JO8oBtkzw8UOoH_cdR4f g\&bvm=bv. $91665533, \mathrm{~d} . Z W U$.

[91] Styles D, Jones MB. Current and future financial competitiveness of electricity and heat from energy crops: a case study from Ireland. Energy Policy 2007;35(8):4355-67.

[92] International Society for Miscanthus and perennial Energy Grasses. Miscanthus statistics. [April 20, 2015]; Available from: http://www.miscanthus-society.com/.

[93] European Commission. The 2003 CAP reform. Luxembourg: Office for Official Publications of the European Communities; 2004.

[94] Bundesministerium für Ernährung und Landwirtschaft. Umsetzung der EU-Agrarreform in Deutschland. Berlin: Bundesministerium für Ernährung und Landwirtschaft; 2015.

[95] Lorbacher FR. Anbau und thermische Nutzung von Miscanthus. Darmstadt: Kuratorium für Technik und Bauwesen in der Landwirtschaft e.V. (KTBL); 2012. 